\title{
Intensification of Cadet's Foreign Language Competence Formation Through the Role-Playing Games
}

\author{
Hrebeniuk Lesia \\ ORCID https://orcid.org/0000-0003-4090-8980 \\ Military institute of Taras Shevchenko National University of Kyiv
}

\begin{abstract}
Knowledge of a foreign language for an officer, is not only requirement of today`s world, but also a way to achieve interoperability in military sphere with NATO countries. Modern challenges and threats for the state`s security causes absolutely new approaches for education and training future officers of the Armed Forces of Ukraine.

The article considers the importance of role-playing games as a method for intensifying formation of foreign language competence of cadets from higher military educational institutions. Effective foreign language communication under conditions of international peacekeeping and security operations, will greatly facilitate the process of interaction in foreign language environment. Fulfillment of professional duties and everyday tasks among future officers who speak foreign language depends, precisely, on practical training and development of communicative situational tasks. Thus, there is an urgent need to replace the traditional methods of teaching with new, effective and motivational ones. The author outlines the advantages and disadvantages of applying roleplaying games during classes. It is noted that simulation of professional situations at lessons through the roleplaying games increases cadet's motivation for learning foreign language, and also they are an effective mean of mastering knowledge, skills and abilities in specific foreign language environment taking into consideration lack of time, and also undoubtedly contributes to enhancement of cognitive activity.
\end{abstract}

Key words: foreign language competence, interactive learning, role-playing games, learning motivation, activity, cognitivism.

Introduction. Modern scientists from Ukrainian military educational institutions are looking for intensifying methods of teaching cadets under changing conditions. Newly-faced challenges and threats made us achieve interoperability with NATO member countries as quickly as possible. That is why appeared an urgent need of changing the old approaches to modern and effective ones.

Methodology. Among 3 main models of learning, active passive and interactive, only the last one represents active interaction between students and a teacher. According to O. Pometun [4] definition, interactive learning is a special form of organization cognitive activity, which has defined, predictable goal - to create comfortable learning conditions under which each student will feel his own successful and intellectual abilities. Interactive learning includes: modeling of life situations related to the direct fulfillment of official duties by serviceman, the use of role and business games, problem solving and tasks based on the analysis of orders and the conditions for the accomplishment of tasks. 
Discussion. A role-playing game is a kind of triangle, which comprises, gaming and educational activities. First of all, cadets perceive it as playing activities, where they can try different roles in different situations. But in this case, educational nature of role playing game is often not realized. But as for a teacher, he/she deliberately considers the role-playing game as a form of practicing communication skills. And the aim of a game lies primarily in the development of speaking skills and abilities [6].

In most cases, teacher is not able to comprehend correctly what does cadet could say from his own. In this case, the teacher is advised to be guided by the principle of conscious activity. The basis of this principle are the following postulates [5] for a lecturer: 1) he/she must know the individual interests of students; 2) create such situational conditions for students that requires from them to identify and explain the differences between facts and knowledge, but this should not be done within available time; 3) should be aware of conditions that facilitate involvement of students in collective forms of work (in our case, the team has a training group of future officers of the AFU).

Role-playing game is an imagery situation where students play characters and roles and interact with each other. It will help cadets with the language and make them comfortable and confident to do the same in real life. The best type of role-playing game is one that creates a sense of conflict. Role-playing games help to develop: empathy, interpersonal skills, ability to handle future scenarios [4]. A role-play as a teaching strategy, provides students an equal playing field, where they all have the same opportunity to engage and learn through imaginative process together. Role-playing is an instructional method including active participation, dramatization, participants and characters [8]. It helps to arouse feelings and provoke an emotional response by using real-life simulation, script-free simulation which creates understanding of behaviors.

These are advantages and disadvantages of using the role playing games during lessons in military educational institutions.

Advantages of role-playing games:

- narrow distance between new comers and professionals;

- bridge the gap between understanding and confidence;

- provide opportunity to explore feelings and attitudes to different specific situations;

- help to make abstract problems more concrete; 
- involves experiential learning;

- integrates knowledge and skills;

- develop communication and cultural competence;

- improve decision-making and problem solving skills;

- enhances observation skills and comprehension of complex behaviors under different conditions and lack of time;

- provide immediate feedback;

- involve comparing and contrasting positions for one issue;

- promote lifelong learning and discover cognitive skills;

- allow exploration of different types of scenarios;

- stimulate team building;

- allow to practice skills for further development;

- provide information for cadets with sensitive situations (cultural, ethnical);

- allow to test communication skills;

- students can experiment with decisions in a risk-free environment.

As for disadvantages of role-playing games they are the following:

- limited to small groups;

- over exaggerating roles;

- too dramatic;

- role development insufficient;

- stereotyping;

- unfavorable environment for discipline;

- resistance to participate;

- involves large time commitment for faculty;

- seem like a real game, but learning results are unknown;

- difficult to evaluate.

Such communicative method of learning foreign language is highly effective and is achieved through the implementation of communicative-cognitive tasks with the help of a foreign language $[3 ; 10 ; 14]$. Work in small groups should be used to solve complex problems that require collective intelligence. If the efforts and time spent do not guarantee the desired result, it is better to choose a pair of work or any of the above technologies for quick interaction 
$[1 ; 2 ; 9 ; 11 ; 12]$. It is advisable to use small groups only when the task requires a joint, not an individual job $[7 ; 13]$.

Conclusion. The most important advantage of applying interactive teaching methods is the extremely important simulation of specific situations, that may occur when performing duties in international operation with the help of role-playing games. In this case, a lecturer is able to direct the lesson material for more practical use, increase motivation for cognitive activity among future officers, and improve communicative skills for achieving the joint task with further participation in international peacekeeping and security operations. It was also defined, that role-playing games, as well as game training, reflect the problem of certain situational tasks and is an effective means of improving knowledge, skills under conditions of foreign environment and lack of time. In this case, it is possible to highlight certain statements of the problem, which will determine the role-play and its didactic content.

Further research will require the development of a didactic filling of role-playing games with foreign language learning future officers in the training future officers for international peacekeeping and security operations.

\section{References}

1. Vakoliuk T. V. Osoblyvosti provedennia rolovoi hry z vykorystanniam zorovoi opory $z$ metoiu formuvannia inshomovnoi komunikatyvnoi kompetentsii kursantiv ta slukhachiv [Peculiarities of the role-playing game using the visual support in order to form the foreign language communicative competence of cadets and listeners]. Visnyk Natsionalnoi akademii Derzhavnoi prykordonnoi sluzhby Ukrainy. Seriia: Pedahohika. 2015. Issue 5. URI: http://nbuv.gov.ua/UJRN/Vnadped_2015_5_3.

2. Petko L.V. Natsionalnyi komponent u formuvanni profesiino oriientovanoho inshomovnoho navchalnoho seredovyshcha $v$ umovakh universytetu [National component in the formation of professionally oriented foreign language learning environment in the university]. Naukovi zapysky. Seriia: Pedahohichni ta istorychni nauky. Kyiv: Vyd-vo NPU im. M. P. Drahomanova, 2014. Issue 117. Pp. 125-135.

3. Petko L.V. Profesiino oriientovani tekhnolohii navchannia IM yak zasib formuvannia profesiino oriientovanoho inshomovnoho navchalnoho seredovyshcha $v$ umovakh universytetu [Professionally oriented technologies of foreign languges teaching as a means of forming professionally oriented foreign language learning environment in the conditions of university]. Kyiv: TOV «NVP Interservis», 2015. P. 179-188.

4. Pometun O.I. Suchasnyi urok. Interaktyvni metody navchannia: naukovometodychnyi posibnyk. Za redaktsieyu O.I. Pometun [Modern lesson. Interactive teaching methods: instructional handbook], Kyiv: Vyd-vo A.S.K. 2004. 192 p.

5. Ryzhykov V.S. Teoriia ta praktyka ihrovoho navchannia v profesiinii pidhotovtsi maibutnikh yurystiv: monografiya [The theory and practice of role-playing in training future lawyers: a monograph], Kherson: TOV «Ailant». 2011. 215 p. 
6. Tarnopolskyi O.B. Geimifikatsiya v navchanni inozemnykh mov u vyshchii shkoli [Gamification in foreign languages teaching at high school], Modern technologies in English teaching and culture. Foreign languages. 2018. Pp. 15-22.

7. Turchynova H.V. Psykholinhvistychni peredumovy ovolodinnia inozemnoiu movoiu dlia spetsialnykh tsilei [Psycholinguistic prerequisites for mastering a foreign language for special purposes]. Naukovi zapysky: [zbirnyk naukovykh statei]. Kyiv: Vyd-vo NPU imeni M. P. Drahomanova, 2011. Issue LXXXXVIII (98). Pp. 201-207.

8. Bastable S. Nurse as educator: Principles of teaching and learning, 4th ed. Burlington, MA: Jones \& Bartlett. 2015. Pp. 492-667.

9. Kovalynska I.V., Ternopilska V.I. A Survey of multicultural education in Ukraine: state approach // Science and practice: Collection of scientific articles. - Thorpe Bowker. Melbourne, Australia, 2016. P. 256-259.

10. Pet'ko L.V. Development of students' cognitive activity in foreign language teaching by using analogy method // Actual problems of globalization: Collection of scientific articles. - Midas S.A., Thessaloniki, Greece, 2016. P. 232-237.

11. Pet'ko L.V. Teaching methods and the formation of professionally oriented foreign language learning environment in conditions of university. Intellectual Archive. 2016. Volume 5. No. 4 (July/August). Toronto : Shiny Word Corp., Canada. PP. 73-87.

12. Pet'ko L.V. Teaching of students' professionally oriented foreign language writing in the formation of professionally oriented foreign language learning environment. // Economics, management, law: innovation strategy: Collection of scientific articles. -

Henan Science and Technology Press, Zhengzhou, China, 2016. P. 356-359.

13. Teaching: Making a Difference. 3rd Edition / Churchill R. and others.. 2015. 656 p.

14. Stewart K., D. Cremin D., Mills M., Phipps D. Non-technical interoperability: The challenge of command leadership in multinational operations. 2004. URL: http://dodccrp.org/events/10th_ICCRTS/CD/papers/298.pdf

\section{Translation of the Title, Abstract and References to the Author's Language}

\section{УДК 372.881}

Гребенюк Л.В. Інтенсифікація формування іншомовної компетентності у курсантів через рольові ігри.

Знання іноземної мови не лише вимога сучасності, а й шлях до досягнення взаємосумісності учасників у військовій сфері з країнами-членами НАТО. Сучасні виклики та загрози безпеці нашої держави диктують нові підходи до підготовки майбутніх офіцерів Збройних Сил України. У статті розглядається значення рольових ігор як методу інтенсифікації формування іншомовної компетентності у курсантів вищих військових навчальних закладів. Ефективна іншомовна комунікація у міжнародних операціях із підтримання миру і безпеки значною мірою полегшує процес взаємодії в іншомовному середовищі. Виконання професійних обов'язків майбутніми офіцерами іноземною мовою залежить від їх практичної підготовки та відпрацювання комунікативних ситуативних завдань. Тому, виникає необхідність пошуку заміни 
традиційних методів навчання більш новими, ефективними та мотиваційними, адже неможливо забезпечити якісне виконання вищезазначених завдань без використання інтерактивних методів навчання. При цьому, надзвичайної важливості набуває імплементація іншомовних знань через застосування рольових ігор на заняттях. Автором визначено переваги та недоліки застосування рольових ігор під час проведення занять. Зазначається, що моделювання професійних ситуацій на заняттях за допомогою рольових ігор підвищує мотивацію курсантів до вивчення мови, а також є ефективним засобом засвоєння знань, навичок, умінь у конкретному іншомовному обстановці в умовах дефіциту часу, що беззаперечно сприяє підвищенню пізнавальної діяльності.

Ключові слова: майбутні офіцери, іншомовна компетентність, інтерактивне навчання, рольові ігри, мотивація до навчання, когнітивізм.

\section{Гребенюк Л.В. Интенсификация формирования иноязычной компетентности у курсантов через ролевые игры.}

Знание иностранного языка - это не только требование современности, но и путь к достижению совместимости служащих в военной сфере. Современные вызовы и угрозы безопасности нашего государства диктуют поиск новых подходов в подготовке будущих офицеров Вооруженных Сил Украины. В статье рассматривается значение ролевых игр как метода интенсификации формирования иноязычной компетентности у курсантов высших военных учебных заведений. Эффективная иноязычная коммуникация в международных операциях по поддержанию мира и безопасности в значительной степени облегчит процесс взаимодействия в иноязычной среде. Выполнение профессиональных обязанностей будущих офицеров на иностранном языке зависит уровня практической подготовки и отработки коммуникативных ситуативных задач. Таким образом возникает острая необходимость замены традиционных методов обучения более новыми, эффективными и мотивационными. При этом, чрезвычайной важности приобретает имплементация знания ИЯ через применение ролевых игр на занятиях. Автором определены преимущества и недостатки применения ролевых игр во время проведения занятий. Отмечается, что моделирование профессиональных ситуаций на занятиях с помощью ролевых игр повышает мотивацию курсантов к изучению ИЯ, а также выступает эффективным средством усвоения знаний, навыков, умений в конкретной иноязычной обстановке в условиях дефицита времени, что, безусловно, способствует повышению познавательной деятельности курсанотов.

Ключевые слова: будущие офицеры, иноязычная компетентность, интерактивное обучение, ролевые игры, мотивация к обучению, когнитивизм.

\section{Література}

1. Ваколюк Т. В. Особливості проведення рольової гри з використанням зорової опори з метою формування іншомовної комунікативної компетенції курсантів та слухачів. Вісник Національної академї̈ Державної прикордонної служби Украӥни. Серія: Педагогіка. 2015. Вип. 5. URI: http://nbuv.gov.ua/UJRN/Vnadped_2015_5_3.

2. Петько Л.В. Національний компонент у формуванні професійно орієнтованого іншомовного навчального середовища в умовах університету. Наукові записки. Серія: Педагогічні та історичні науки / М-во освіти і науки України, Нац. пед. ун-т ім. М. П. Драгоманова. Київ: Вид-во НПУ ім. М. П. Драгоманова, 2014. Вип. 117. C. $125-135$. 
3. Петько Л.В. Професійно орієнтовані технології навчання IM як засіб формування професійно орієнтованого іншомовного навчального середовища в умовах університету. Київ: ТОВ «НВП Інтерсервіс», 2015. С. 179-188.

4. Пометун О.І., Пироженко Л.В.. Сучасний урок. Інтерактивні технології навчання: науково-метод. посібник. / за ред. О.І.Пометун. Київ: Вид-во А.С.К., 2004. $192 \mathrm{c}$.

5. Рижиков В.С. Теорія та практика ігрового навчання в професійній підготовці майбутніх юристів: монографія. Херсон: ТОВ «Айлант», 2011. 215 с.

6. Тарнопольський О.Б., Кожушко С.П., Кабанова М.Р. Гейміфікація в навчанні іноземних мов у вищій школі. Сучасні технології навчання іноземних мов і культур. Іноземні мови. 2018. № 3. С. 15-22.

7. Турчинова Г.В. Психолінгвістичні передумови оволодіння іноземною мовою для спеціальних цілей. Наукові записки: [збірник наукових статей] / М-во освіти і науки, молоді та спорту України, Нац. пед. ун-т імені М. П. Драгоманова ; укл. Л. Л. Макаренко. Київ: Вид-во НПУ імені М. П. Драгоманова, 2011. Випуск LXXXXVIII (98). С. 201-207.

8. Bastable S. Nurse as educator: Principles of teaching and learning, 4th ed. Burlington, MA: Jones \& Bartlett. 2015. Pp. 492-667.

9. Kovalynska I.V., Ternopilska V.I. A Survey of multicultural education in Ukraine: state approach // Science and practice: Collection of scientific articles. - Thorpe Bowker. Melbourne, Australia, 2016. P. 256-259.

10. Pet'ko L.V. Development of students' cognitive activity in foreign language teaching by using analogy method // Actual problems of globalization: Collection of scientific articles. - Midas S.A., Thessaloniki, Greece, 2016. P. 232-237.

11. Pet'ko L.V. Teaching methods and the formation of professionally oriented foreign language learning environment in conditions of university. Intellectual Archive. 2016. Volume 5. No. 4 (July/August). Toronto : Shiny Word Corp., Canada. PP. 73-87.

12. Pet'ko L.V. Teaching of students' professionally oriented foreign language writing in the formation of professionally oriented foreign language learning environment. // Economics, management, law: innovation strategy: Collection of scientific articles. - Henan Science and Technology Press, Zhengzhou, China, 2016. P. 356-359.

13. Teaching: Making a Difference. 3rd Edition / Churchill R. and others.. 2015. 656 p.

14. Stewart K., D. Cremin D., Mills M., Phipps D. Non-technical interoperability: The challenge of command leadership in multinational operations. 2004. URL: http://dodccrp.org/events/10th_ICCRTS/CD/papers/298.pdf 